\title{
Financial Markets and the Global Debt Crisis: Toward a New Architecture for A More Reliable Financial Sector ${ }^{*}$
}

\author{
Hans-GeORg Petersen** \\ AleXANDER Martin WiegelmanN***
}

\section{ABSTRACT}

The breakdown of the financial markets in 2007 and the ensuing debt crisis in the EU has produced enormous mistrust in financial products and the monetary system. The emergence of shadow banking also changed the behavior patterns of management so that its self-interest dominated the interests of shareholders and the other stakeholders. These false incentives led to merger processes in the financial system resulting in market structures in which single institutions became too big or too connected to fail. The empirical developments and the political counter-measures described in this article point to the fact that the macroperspective has been dominant, neglecting individual irresponsibility and failure.

Key words: capital funding, corporate social responsibility, financial markets, principal agent problems, risk management

\section{RESUMEN}

La caída de los mercados financieros en 2007 y la subsecuente crisis de la deuda en Estados Unidos produjeron una enorme desconfianza en los productos financieros y en el sistema monetario. El surgimiento del sector bancario en la sombra (shadow banking), también ha cambiado los patrones de conducta de la administración, de manera tal que los intereses de esta última dominaron los de los accionistas y otros tenedores de acciones. Estos falsos incentivos llevaron a fusionar procesos en el sistema financiero que tuvieron como resultado el surgimiento de estructuras mercantiles por medio de las cuales cada institución por separado se hizo demasiado grande o demasiado cercana al fracaso. Los desarrollos empíricos y las contramedidas políticas descritos en este artículo apuntan hacia el hecho de que ha dominado la perspectiva macro, lo que de algún modo niega la irresponsabilidad y el fracaso individuales.

Palabras clave: Fondeo de capital, responsabilidad social corporativa, mercados financieros, problemas del agente principal, administración de riesgos

* The authors would like to thank the anonymous referees for its valuable comments and hints. Naturally, responsibility for errors remains ours.

** Faculty of Economics and Social Science, University of Potsdam, Tax and Transfer Research Group, Berlin, hg@profpetersen.de

*** Faculty of Economics and Social Science, University of Potsdam, Tax and Transfer Research Group, Berlin, alex.wiegelmann@gmail.com 


\section{INTRODUCTION}

The financial system, consisting of financial markets, banks, and insurance firms, has always been heavily dependent on its clients' confidence in the sustainability of the financial products it provides. Hence, financial products have often been characterized as credence goods where "the sellers act as experts determining the customers' requirements" (Emons, 1997). The functional capability of such markets is only preserved if the sellers in a mid- and long-term ensure the quality of the products supplied and are able to overcome the temptation to exploit the existing information asymmetry in their short-term interests to maximize their own income and wealth. The concept of corporate social responsibility (CSR), developed in a long process of professional experience, has delivered a value base for intrinsic motivation, which has been a certain guarantee for consumer protection. If mutual trust is eroded more and more by a growing number of unsound sellers, financial markets become inoperable.

The emergence of the unregulated shadow banking system (Stein, 2010) and the subprime credit crisis (Diamond and Rajan, 2009; Mishkin, 2011) have often been mentioned as the most important causes for the global financial crisis. Therefore, especially macro-prudential approaches to financial regulation have been proposed (Hanson, Kashyap, and Stein, 2011). But as significant as the macro-perspective might be, individual misbehavior of market agents is another important fact: the vastly increasing number of market-based financial institutions has required the engagement of a large staff that is obviously quite differently motivated and much more extrinsically oriented than their peers at conventional banks, who are subject to higher risks to their reputations. Sellers' interests in the form of high salaries and bonuses became dominant, and this behavior has also infected the staff's behavior within the conventional banking system. Not only have the Basel accords, government supervision, and regulation alone failed to work but the self-regulation through csR totally collapsed. The long-term functioning of financial markets has been sacrificed for the sake of short-term selfish interests of management and staff.

Apart from the predominately macro-orientated mainstream publications on the causes of the global financial crisis, this article sheds light on the individual responsibilities of principals and agents. We will demonstrate that the behavioral assumptions of institutional economics deliver not only an adequate diagnosis for the micro-prudential causes of the global financial crisis, but also arguments for therapy. Before the latter is highlighted in more detail, we briefly describe the basic role of the financial sector as an important economic intermediary in section 2. Section 3 draws an alternative picture of the crisis, namely the abundant liquidity in global financial markets, stressing the role of financial innovations and emerging shadow banking 
as well as the simultaneous euro implementation with its impacts on the public debt in single eurozone member countries. As already mentioned, section 4 contributes some background explanations derived from institutional economics and risk management. Section 5 draws some important conclusions for developing more reliable national as well as international financial markets.

\section{Social Responsibility, the Monetary System, and the Crisis}

Without doubt the monetary sector plays an important role in the growth processes in highly developed countries. In real life, the risk always exists that the power of one sector could become dominant and even endanger the future development of a well-balanced societal system. Hence, a first step must be to enumerate the specifics of social responsibility; a second step is to determine the role of the monetary system in democratically-steered market economies; and a third step is to identify the causes of the crisis of the financial markets.

\section{Individual Responsibility, Capital Formation, And Economic Agents' Behavior}

The concepts of social responsibility are closely connected with the ethical foundations of open societies. Following the approach of methodological individualism in the philosophy of science, open societies are defined as societies with decentralized democratic decision making and a well-balanced market system, which ensure a dynamic equilibrium between the social goals (peace, liberty, welfare, and justice) and the social instruments (family, morality, law, and market) (for details see Petersen, 1993 and 2004; and Petersen and Mueller, 1999). In such a society, individual property rights play a decisive role. The individuals act in barter or market transactions and generate individual income, which is partly consumed and partly saved if the individuals possess sufficient human capital (e.g., a high level of vocational education) (Petersen, 2012a; 2012b).

Savings are accumulated over time and generate equity capital, which can be invested in additional human capital (through further education) or in real capital (e.g., farmland or industrial investments). Capable people become entrepreneurs when they invest capital they have generated by their own work. Besides income from labor, capital income is another income source, which ensures the further existence of an individual person. It should come as no surprise that such an individual 
tries to sustain his / her equity capital and as far as possible even to increase it: the individual acts in self-responsibility. In a family context, savings and equity capital play a dynamic role because parents (or forebears) not only take care of themselves but also of the children and grandchildren (or the successors); this is the so-called intergenerational responsibility. In more complex modern societies with elaborate institutional settings like large corporations in the private sector and representatively organized democratic institutions, the reciprocity within the family is extended to the whole society, in which strong society members take care of the less capable members by implementing transfers based on altruistic elements. This also reflects ideas on social responsibility and solidarity. Hence, individual property rights over equity capital are complemented by social liability, which at least in some countries is even expressed in the constitution. ${ }^{1}$ This social liability has been the basis for the development of the concept of corporate social responsibility, described in more detail below (section 4 ).

In complex, democratically-ruled societies, in addition to the citizens, who are the principals in both the political and economic spheres, the corporate and the government sectors must serve citizens' individual interests. Managers in private corporations as well as banks, insurances companies, and public institutions are the agents, controlled via competition in more or less efficient markets or elections in the political setting. The principals need the best information to evaluate the quality of agents' performance and to control their actions. If information is asymmetric in favor of agents and control is insufficient, principal-agent problems (PAP) arise, jeopardizing well-being in entire societies.

Agents start to hide risk and misinform the principals, and decision making regarding investment of equity capital and involvement in public affairs becomes highly difficult. Hence, institutional arrangements (public regulations or self-regulation) to ensure transparency in economic and political markets are of utmost relevance for preventing agents from deploying exploitation strategies against the principals. If efficient regulations are sorely missing, fraud and corruption destroy fairness and justice, leading to mistrust in governance in the private and public sector, respectively.

Concrete behavioral problems occur if the responsibility for capital is transferred from the owner (shareholder or principals) to management (CEOs or agents). Because of asymmetric information, the management can develop its own interests, which could at least partly be in conflict with the owners' interests. If management

\footnotetext{
${ }^{1}$ See, e.g., the German Grundgesetz Article 14,2: "Property entails obligations. Its use shall also serve the public good." The concept of the social market economy is closely connected with the common welfare obligation of private property.
} 
contracts are short-term, reporting and controlling can be misused to exaggerate the current profit line; that positive picture is then used as justification for salary increases and additional bonuses, meaning higher costs for the future and even endangering the further existence of the entire company. Then the individual behavior of the managers (CEOS of banks, insurance companies, and rating agencies, asset managers, etc.) conflicts with the collective equity capital interests of the shareholders in the literature such problems have been discussed in terms of rationality traps, prisoners' dilemma, or agents' moral hazard behavior.

With the global financial crisis in mind, responsibility does not fall on agents alone. Short-term chances for enormous profits have also infected the behavior of the principals: greed and mammonism have dominated over traditional principles for sound investments. High-interest yields were not understood as indicators for high risks, but for handsome profits and rapid property growth. Therefore, the spirit of the time was to blow up the property bubble until it burst. All rational control mechanisms have been overruled by individual misbehavior.

If the whole financial system is playing Russian roulette and creating "casino capitalism" (Sinn, 2009), there is only a very limited chance for the legal system to control misbehavior and fraud. There are not enough district attorneys and expert investigators to monitor almost the entire national banking and insurance system and especially not their international connections. A constitutional democracy with all its institutions is unable to absorb the shocks of a moral breakdown within a whole economic sector. Therefore, principals as well as agents have to be seriously reminded that both must act in an ethically correct manner if the functioning of financial markets and the trust in their products are to be ensured for future generations. Therefore, public regulation has to be supplemented by self-regulation of the sellers and buyers in the financial markets, both of whom also have a fundamental interest in the (long-term) sustainability of financial markets.

\section{The Fundamental Role of Money, Credit, And Banking in Market Economies}

The modern monetary system is a fundamental invention of mankind. The welfare of a society is created in the productive sectors, that is, the primary (agricultural) and secondary (industrial) sectors. With increasing division of labor and specialization, the complexity of a society increases enormously, so that a highly developed monetary sector, as an important part of the tertiary sector, is a basic prerequisite for improving a society's growth potential. The implementation of a monetary system 
dramatically reduces the transaction costs of a barter economy and works almost as a "lubricant" for further development. There is no doubt about it: the financial sector has contributed substantially to the welfare gains in highly developed societies.

But, as usual, there is a reverse side of the coin: a monetary system has to play a supportive role for the economic process because well-being is predominantly created by the primary and secondary sectors. While in the primary and secondary sectors the equity capital of the business owner (sole trader or shareholder) dominates, the financial sector is much more dependent on deposits and borrowed funds: the Basel II Accord demands minimum capital requirements to secure a bank's solvency, which has to be between 1.6 and 12.5 percent depending on the individual risks structure. Furthermore bank capital is difficult to define and highly volatile. Since banks predominantly work with borrowed capital, conflicts of interest emerge, which have been described by modern institutional economics and were already mentioned above: the PAP and moral hazard.

In a macroeconomic view, net savings take place in households, while the business and the government sectors are usually debtors. In other words, the business sector (including the banks) is acting with more or less borrowed money while the state is totally dependent on taxpayers' money. Therefore, in both sectors the hazard exists that the agents (bank managers, politicians, and bureaucrats) acting with borrowed capital might handle it more carelessly than the principals (capital owner or taxpayer) would with their own capital. If this kind of behavior becomes dominant, societies are confronted with market and government failures, which jeopardize well-being and future development. Hence, democratically-controlled state and international regulations for the financial sector (the banking and insurance system) are necessary to protect investors and owners of capital (the principals) against exploitation by the managers of the financial sector (the agents), who in reality often show moral-hazard behavior by taking too many risks with borrowed capital. But as mentioned above, agents' long-term interests must be stressed, even if that would mean fewer salary hikes and bonuses in the short run. Management contracts and remuneration have to be oriented to the long term to create a certain job security and personal responsibility so that short-term income interests are dominated by long-term reasoning.

\section{Causes of the Crisis - Too Big and Too Connected to Fall}

A modern, efficient financial sector steered by responsible financial managers acting in the interests of the capital owner but also in their own personal profit interests remains an important target of national and international economic policy and regulation. The 
abolishment of capital transaction controls and the globalization process have broadened the financial markets, created new financial products, and have allowed new types of financial institutions to emerge, less or almost totally unregulated by national supervisory authorities. Especially in the United States, a shadow banking system emerged, which gained tremendously in relevance and even started to dominate the classical banking structures. In such an environment, "subprime mortgages" (in reality an irresponsible pyramid or Ponzi scheme) could be "invented" (Mishkin, 2011), which almost destroyed the monetary system in the 2008 crisis. The exaggerated risk behavior of U.S. shadow banks, which initially created high profits, has also infected that of the European banks, who founded their own investment branches in the U.S.

From a short-term perspective, even very dubious profits made by extreme risktaking increase the rate of return, which induces rising market capitalization in stock markets. If conventional banks do not follow suit, they lose in market capitalization and are in danger of a hostile takeover. Therefore, more and more banks had to take increasing risk positions to survive in a wildly accelerating footrace for a better competitive position, finally leading into the near collapse of the financial system. This process was accompanied by a long-term policy of cheap money in the U.S. created by the Federal Reserve System policy and initiated by Alan Greenspan. In Europe, the euro introduced in 1999 also gave rise to the fact that at least in some member states (especially the GIIPSC states: Greece, Ireland, Italy, Portugal, Spain, and Cyprus), the interest rate dropped dramatically. This resulted in greatly increasing public debt levels, especially after the 2008 crisis, which led into the eurozone's 2011 crisis.

The broadening of financial markets has increased the pressures on banks and insurance companies to move into business segments formerly in the hands of specialized financial institutions (like investment banks, private equity funds, hedge funds, etc.). Even German banks with a very good reputation for small- and mid-market services temporarily lost interest in this segment and concentrated on big firms and investment banking services. The short-termed windfalls induced a process of mergers that substantially increased market concentration, posing a threat for future competition. Simultaneously, the international connections intensified because of new financial products created and bought by conventional banks. ${ }^{2}$ Similar processes have taken place all over the world resulting in "systemic" banks. On the one hand, these institutions are considered too big to fail, because bankruptcy of a single bank would now endanger the existence of the national financial system. On the other hand, these institutions are also too internationally connected to fail, which would endanger the supranational or even global financial system. All this was accompanied by more or

\footnotetext{
${ }^{2}$ For the increase in connectedness after the crisis, see Pelizzon (2014).
} 
less inefficient supervisory mechanisms, especially totally insufficiently regulated rating agencies, which are private firms. This led to an increasing number of experts and citizens losing confidence in financial institutions despite the fact that financial products are predominantly "credence goods" as mentioned above.

\section{The Empirical Pictures of the Crisis}

The international capital markets have been characterized by high and increasing liquidity in recent decades, especially after extensive liberalization as a consequence of the fall of the Iron Curtain. Additionally, the periods of consolidation in the budgets of the U.S. under the Clinton administration and the UK induced innovations in the financial markets to provide for alternative investment products. These developments strengthened the leverage effects and enlarged credit potentials in the private sector. Increasingly risky financial products accompanied by the introduction of the new currency in Europe (the euro) led to the financial crisis, in which the exploding public debt in the eurozone has contributed additional risks to an already gloomy prospect.

\section{Liquidity and the CRISIS In Financial Markets}

Beginning in the early 1990s, growing rents in the raw-material-producing countries particularly flooded the international financial markets, which had just been almost totally liberated after the 1990 change. Additionally a long period of strong economic growth was observed in the emerging BRICs (Brazil, Russia, India, China, and South Africa). The raw-material-producing and emerging countries were not able to absorb all the export surpluses in their own countries, so their governments and/or banks looked for profitable investments especially in the highly developed industrial nations. Alternative investment in the really needy developing countries (often "fragile states") (Petersen, 2010) did not take place because of a supposedly lack of "investment security," so their growth remained comparatively moderate.

Figure 1 demonstrates that since the beginning of the 1990s, the savings rates of the oil-exporting and emerging economies strongly increased, while those in the advanced economies slowly decreased. Figure 2 shows that the decline of the savings rate has been especially sharp in Italy, Japan, and the United Kingdom. While the U.S. savings rate also fell to about one percent in 2005, it recovered after the 2007/2008 collapse. 
Figure 1

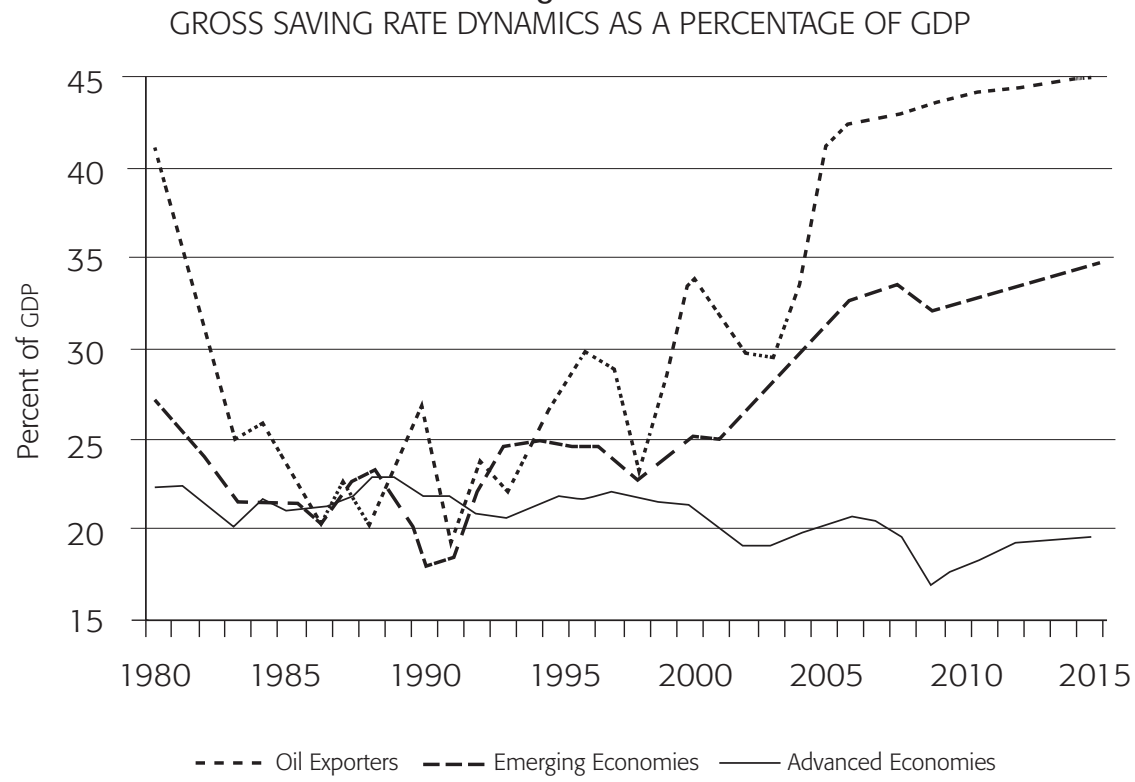

Source: McKinsey Analytics (2010).

Figure 2

HOUSEHOLD GROSS SAVINGS RATE IN ADVANCED ECONOMIES AS PERCENTAGE OF GDP

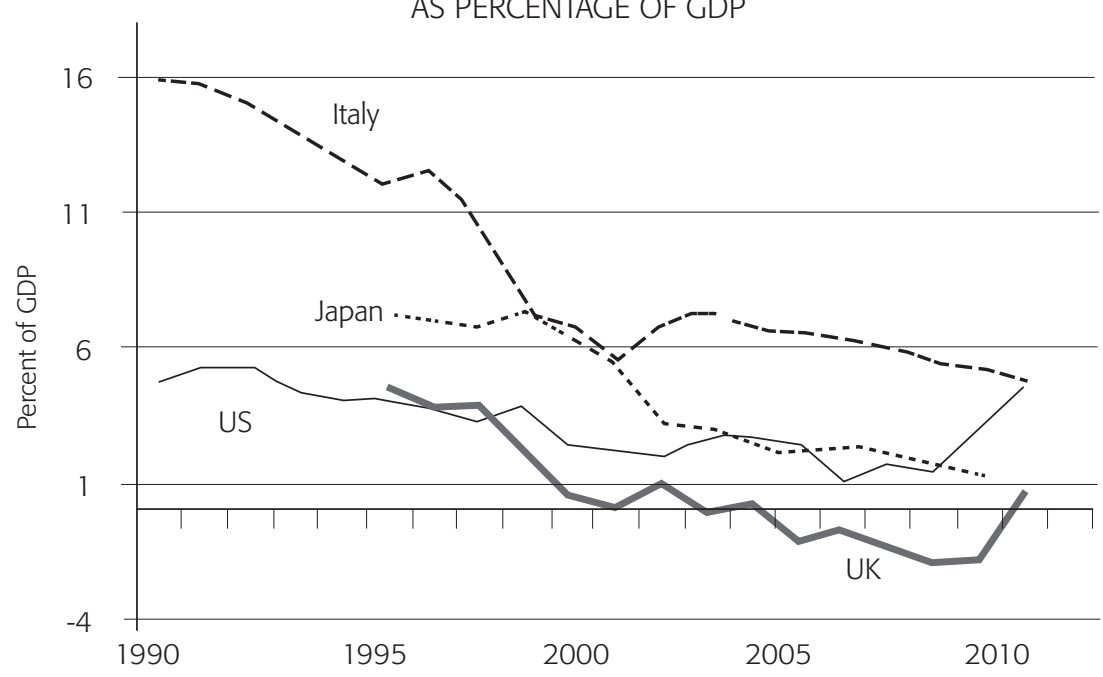

Source: OECD (2011). 
Both figures give clear hints that the excess of savings over desired investment in the past two decades was absorbed in the highly developed countries, the U.S. and European Union member states. ${ }^{3}$ Here, investment predominantly went into new financial products and government bonds. The excess liquidity and the cheap money policy in the U.S. and Europe established the questionable incentive for reducing savings in the high developed countries and increasing their foreign debt.

\section{Financial Innovations and Shadow Banking}

The low-interest policy of the Federal Reserve System (Fed) and the European Central Bank (ЕСВ) consequently caused strongly decreasing rates of return on government bonds so that international investors on the global financial markets searched for profitable investment at higher rates of return, ignoring the fact that higher rates of return are only possible by taking higher risk positions. Here, financial innovations came into play. Numerous new financial products were invented to attract the excess supply of capital:

— single securitizations (e.g., asset-backed securities [ABs])

— multiple securitizations (e.g., collateralized debt obligations [CDO])

— securitization-based derivatives (e.g., credit default swaps [CDS])

— re-securitization and re-hypothecation.

Additionally, new financial institutions emerged or have greatly gained in influence. Conventional or commercial banking was supplemented by a shadow banking system (market-based financial institutions like hedge funds, structured investment vehicles, investment banks, private equity funds, money market funds, insurers, etc.), which conduct credit transformation outside national banking regulations and accords (e.g., Basel I and II). The financial innovations as well as the new financial institutions were becoming increasingly complex so that information about the real risk structures of the different investment products was more or less hidden. This was especially true for multiple securitization structures, where even experts were not able to evaluate the products' quality. This has been demonstrated by false evaluations by the rating agencies (Standard \& Poor's, Moody's, Fitch Rating), interestingly all U.S. private companies. Obviously there has been no product liability for

\footnotetext{
${ }^{3}$ For a critical analysis of "excess saving" see Obstfeld and Rogoff, 2009; Serven and Nguyen, 2010; and Borio and Disyatat, 2011.
} 
financial products either on the national or the international level, while product liability for industrial products is very stringent even internationally.

The empirical development in the U.S., which significantly contributed to the financial crisis of 2007 / 2008, is shown in Figures 3 and 4. Figure 3 demonstrates that since 1985, the shadow banking system (supplying the "financial innovations") was increasingly important. The growth of largely unregulated ABS issuers outpaced the growth of regulated conventional banks' security emissions; in 2008, the volume of the shadow banking sector reached its peak with about US\$20 trillion compared to the conventional banking sector with about US\$11 trillion.

Figure 3

GROWTH OF SECURITY EMISSIONS IN U.S. FINANCIAL SECTORS

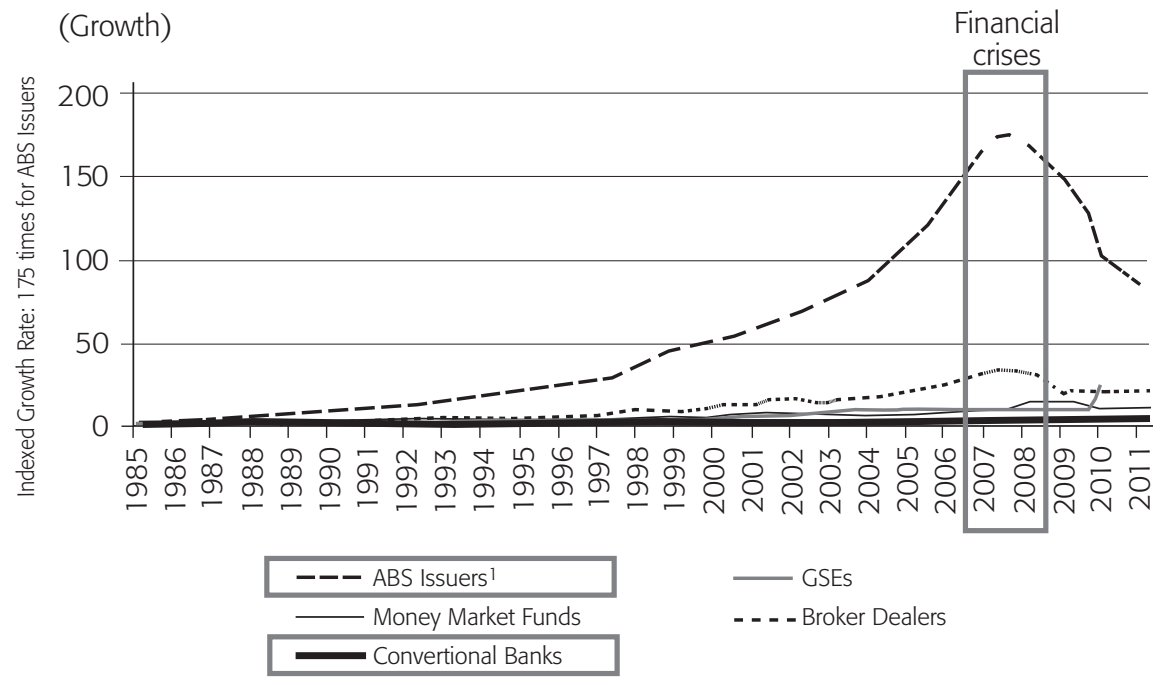

${ }^{1}$ ABS issuers include conduits such as special-purpose vehicles.

Source: Federal Reserve Board (2011) and Wiegelmann (2013).

The so-called true-sale securitizations are divided into the conventional ABSs and collateralized debt obligations (CDOs). Conventional ABss consist of broadly diversified and homogenous credits; their credit worthiness can usually be estimated by actuarial mathematics. However, CDO is an umbrella term for structured bonds, collateralized by much more heterogeneous assets like credits of private companies partly traded on the stock exchange, illiquid property, real estate credits (collateralized mortgage obligations or CMOs), payment requests for automobile loans, credit 
card loans, student loans, consumer credit, public debt titles, etc. Additionally CDOs themselves have been securitized again (re- or even multiple-securitization), so that for investors the risk structures were usually totally hidden. Figure 4 represents the breakdown of true-value securitizations in the U.S. and their development since 1985. The figure illustrates that until the financial crises, subprime mortgages permanently gained in importance, and the same is true for the cDos. However, especially highly complex and risky products dominated the market for true-sale securitizations.

Figure 4

BREAKDOWN OF U.S. TRUE-SALE SECURITIZATIONS

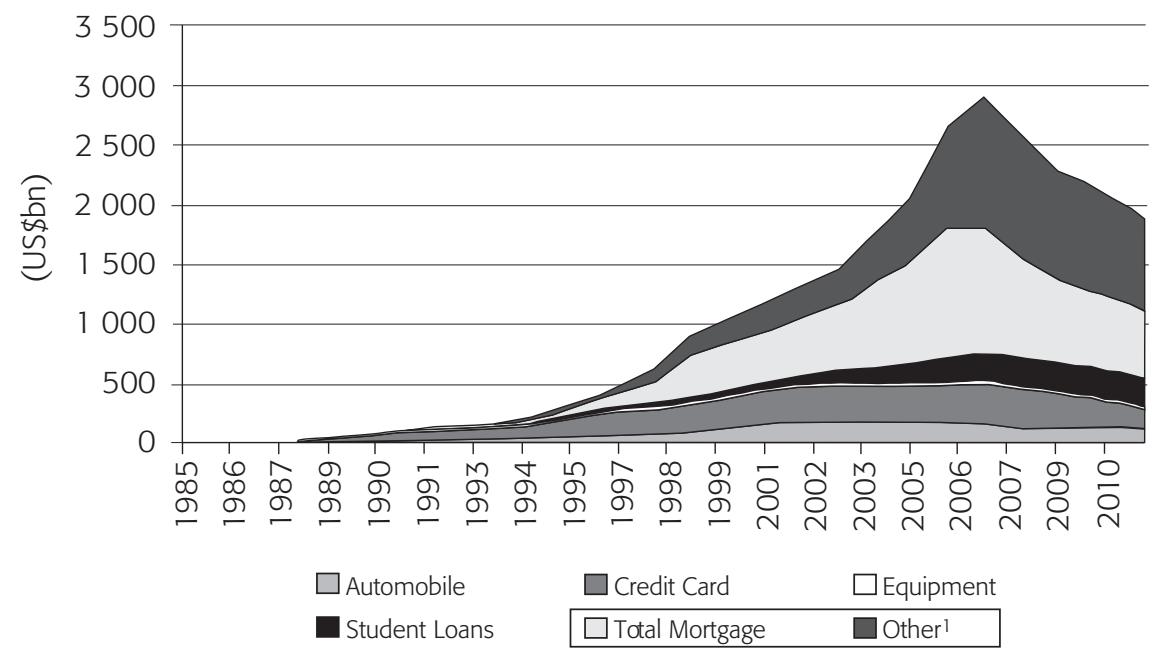

${ }^{1}$ Especially cDos.

Source: Securities Industry and Financial Markets Association (2011) and Wiegelmann (2013).

Hence, established mechanisms for efficient individual risk management were no longer useful. At least the higher yield for some of the products was a rough hint that the risks involved were steadily increasing. And all this happened without any information or warnings to investors. Liability and responsibility considerations obviously did not exist on the side of the product innovators and no product recall -as it is usual for defective products in the industrial and consumption goods sectors- has ever happened. 


\section{Euro Implementation, the Crisis of Credits, And Exploding Public Debt}

Parallel to this period of product innovations on financial markets and the U.S. cheap money policy to overcome the 2000 explosion of the dot-com bubble (collapse of the "New Market"), the European currency zone was implemented. The cheap money policy is reflected in the development of the federal funds rate, shown in Figure 5.

Figure 5

U.S. FEDERAL FUNDS RATE (1952-2012)

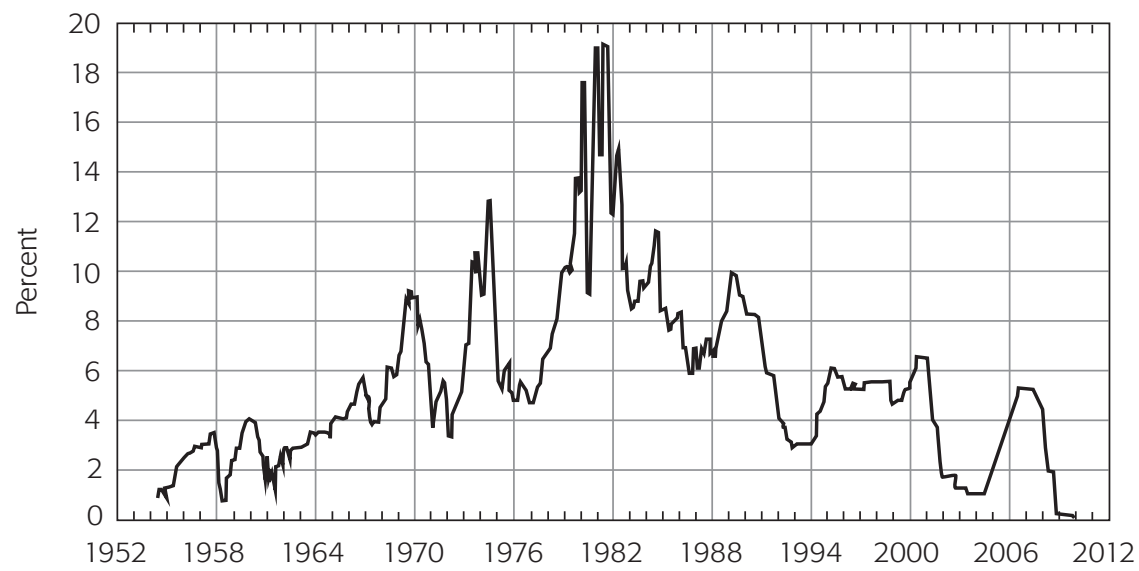

Source: Federal Reserve Bank of St. Louis (2012).

The federal funds rate decreased steadily from the 1980s on (also reflecting declining inflation rates) and almost reached zero percent in the crisis years 2007/2008.

The crisis of credits emerged in several steps:

- The aggressive subprime mortgage policy of the U.S. shadow banking system (including European subsidiary companies, like Deutsche Bank and many German "Landesbanken”) led to lower lending standards and high-risk mortgage products (like adjustable-rate mortgages);

- The limitation of mortgage liability on housing in the U.S.; there is no joint and several liability for individuals like in many European countries; ${ }^{4}$

${ }^{4}$ The slogan is, "Drop off your keys at the bank and get rid of the liability!" 
- Malfunctioning of rating agencies that overlooked the massive problems, especially in the shadow banking system;

- The real estate bubble (Ponzi or pyramid scheme) as a consequence of careless or even irresponsible policies and investment behavior;

- Breakdown of the overheated real estate markets in the U.S. and Europe as well as the collapse of the shadow banking system;

- Infection of commercial banks and insurance companies, which held valueless securities (especially CDOs);

- Overreaction of the rating agencies in down-grading the government debt titles in the U.S. and Europe;

- Collapse of real economic activities in single countries accompanied by significant monetary and fiscal policy reactions;

— Decreasing GDP and increasing interest payments on government debt induced enormous budget deficits;

- The enormous increase in refunding needs in some EU member states caused even stronger rising interest rates;

- Individual countries came close to bankruptcy (GIIPSC);

- Crisis of confidence in the euro system;

- Implementation of financial rescue-parachutes.

Keeping in mind the development in the eurozone, the implementation of the euro, especially the convergence process before the implementation phase, reduced inflation and improved stability in most of the participating EU member states. Figure 6 demonstrates that the process to introduce the euro had an enormous impact on interest rates in the countries of the eurozone; we chose the net yields of 10-year government bonds as an example. It becomes obvious that the euro implementation dramatically reduced interest payments on government bonds especially in the GIIPSC states. In the year of the introduction of the cash euro, 2002, interest rates in almost all member states of the zone dropped to the German level. And the spread in between the interest rates remained very close until the beginning of the crisis in the first half of 2007.

Therefore, the implementation of the euro led to a strong decrease in interest structures in all the member countries with the exception of Germany, which already had very moderate interest rates due to the Deutsche Bundesbank's stringent monetary policy. This decline in national interest payments worked like a business stimulus package, which caused a boom at least in some member countries, whereas Germany remained in stagnation until the measures of the Agenda 2010 developed their full positive impacts. 
Figure 6

NET YIELD OF 10-YEAR GOVERNMENT BONDS IN SOME EUROZONE STATES

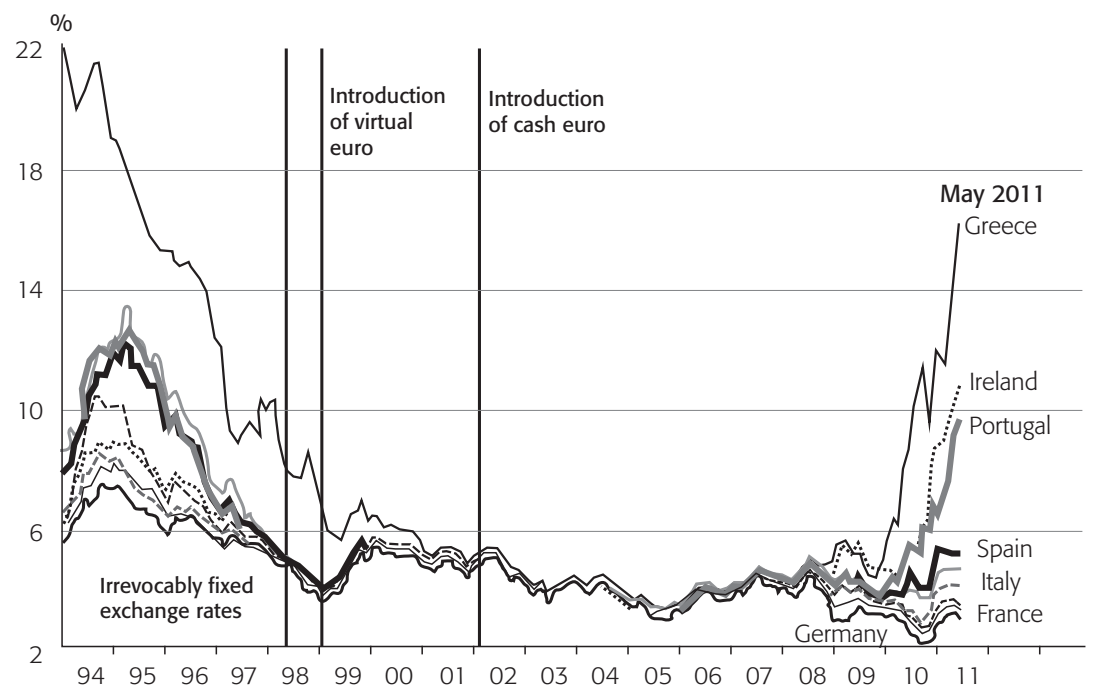

Source: Wikimedia Commons (2012).

The low interest rates have not only influenced economic activities in the member countries, but also induced the governments to increase their public debt because of the cheap money that flooded international financial markets. As a consequence, foreign debt dramatically increased, which at least for a certain period was hidden because of the continuing moderate interest payments in public budgets. But if the public debt exceeds a level of between 60 and 80 percent in relation to GDP, increasing interest rates usually cause a dramatic hike in the interest payments so that exploding budget deficits surface. Hence, these developments induced an increased heterogeneity in the eurozone and the EU. A process of divergence of economic indicators, especially internal inflation rates, began.

Since 2007 / 2008, these processes have step by step and much too slowly been internalized by the rating agencies, which abruptly changed their policies and simultaneously caused a sudden collapse of trust in governments' ability to manage such a crisis. The reflection on the international financial markets was an explosion of the risk component in compound interest rates, which also happened in the eurozone and is depicted in Figure 6 as well.

Citizens in the GIIPSC countries increased consumption levels even more, bought goods and services in the few stable countries in the eurozone (Finland, Germany, Luxembourg, and the Netherlands), and a real exodus of capital from the GIIPSC states 
to the stable states occurred. This is clearly expressed in the so-called target2 balances, which reflect the imbalances of services and capital movements of the single member states. ${ }^{5}$ Figure 7 shows how, since summer 2007, the formerly negligible target2 balances practically exploded and reached their peak in July/August 2012. Since then, the maximum gap, especially between Germany and Spain but also vis-àvis the other member states of the eurozone, has diminished slightly.

Figure 7

ECB TARGET 2 BALANCES (BILLIONS OF EUROS)

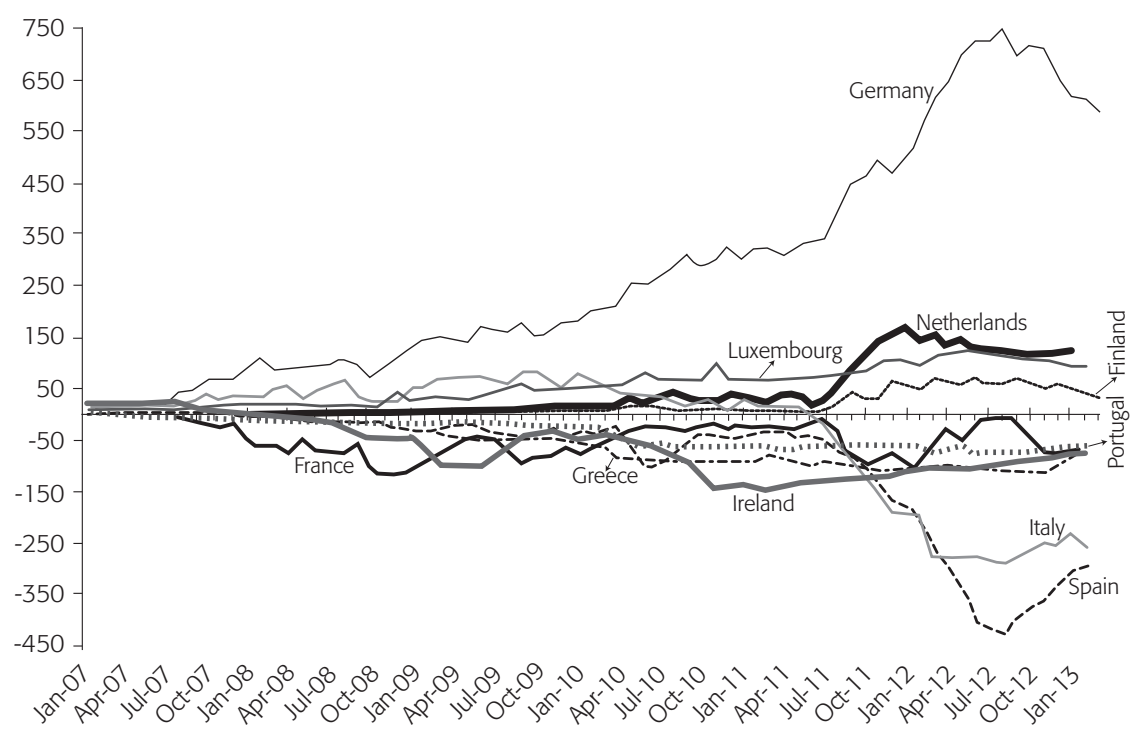

Source: Euro Crisis Monitor (2012).

The slight reversal trend in the target 2 balances since fall 2012 is also reflected in the development of government bonds' net yield. The implementation of the European financial rescue parachutes (Security Market Program [SMP] of the ECB, European Fiscal Stability Facility [EFSF], European Stability Mechanism [ESM], European Fiscal Compact [EFC], European Financial Stabilisation Mechanism [EFSM]) have obviously temporarily calmed down the actors on the international financial markets so that long-term interest rates have also dropped -with some interruptions- since fall 2012 (see Figure 8).

\footnotetext{
${ }^{5}$ For more details on the target 2 balances see, for example, Sinn (2012).
} 
Figure 8

LONG-TERM INTEREST RATES IN THE EUROZONE

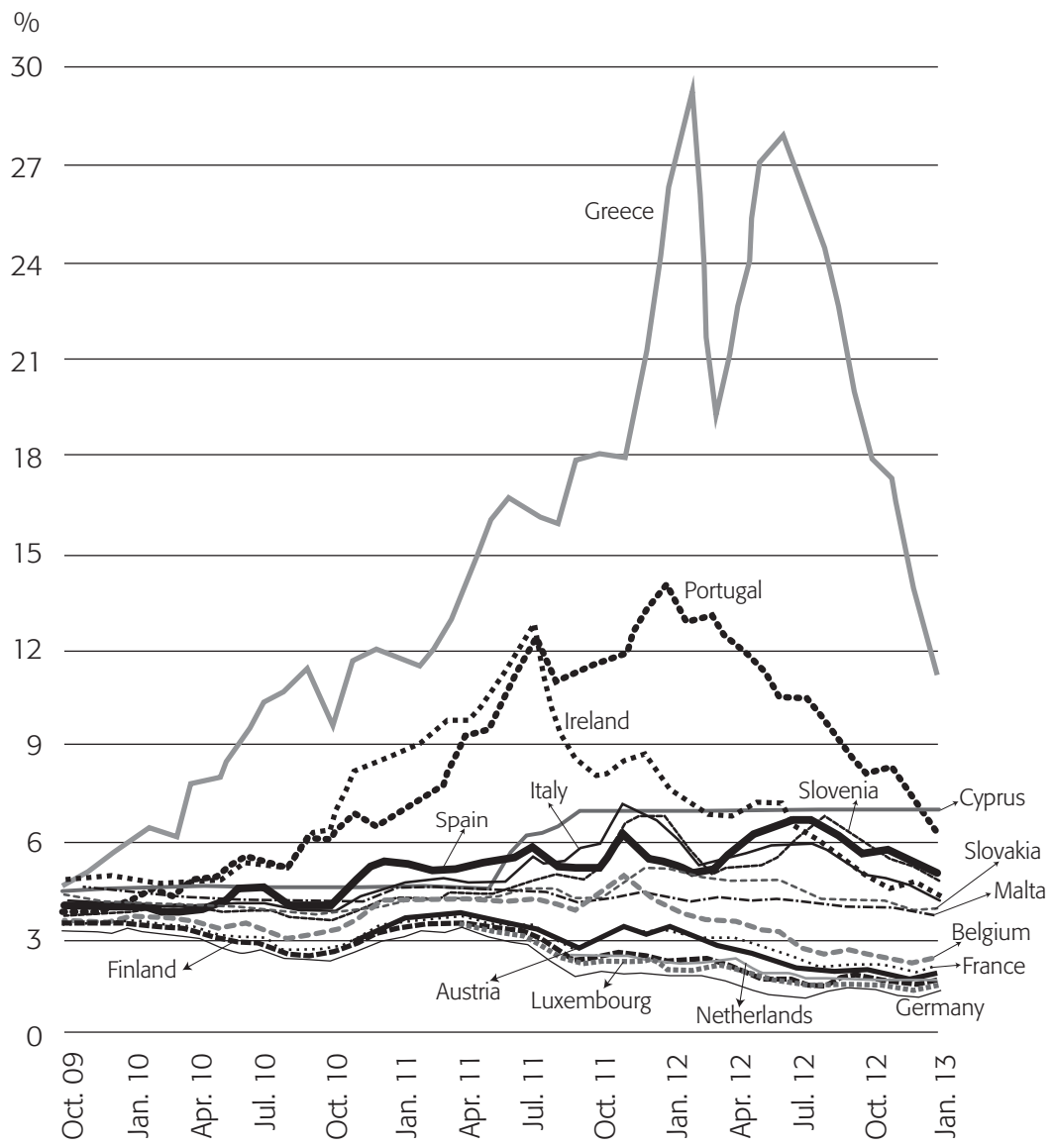

Source: ECB (2012).

Only the future will tell if the political measures being implemented will be sufficient or not. An economic policy in the individual member countries that reduces public deficits and the interest burden in budgets seems to be the only feasible course for consolidating and gaining back the trust in national governments. All the discussions on growth enhancements up to now have been pure rhetoric, because nobody has been able to explain how such programs can be financed without endangering the future again - despite the fact that such concrete programs are badly lacking. 


\section{InStitutional ECONOMICS AS a BACKGROUND EXPLANATION}

Economic theory helps to explain what went wrong especially in the last two or three decades of real life. The aforementioned approaches of institutional economics like the principal-agent problem (PAP) are of utmost relevance as is demonstrated in the following section.

As long as management only relies on equity capital, no PAPs exist for the most part. Even if the entrepreneur has limited information (especially about future trends), he/ she develops his / her own expectations based on experience and arrives at his / her own management decisions regarding expected risks. In the simple neoclassical setting, he/she tries to maximize his/her profits, assuring or even broadening his/her equity capital basis. He/She is interested in sustainable development and even voluntarily internalizes negative external effects, following the rules of fairness (in a Rawlsian sense) and even ensuring inter-generational responsibility in a familial as well as societal context; he/she is acting as a decent tradesman ("ehrbarer Kaufmann"), which in the German literature forms the basis for the concept of corporate social responsibility (Klink, 2008). This idealized context has to be compared with modern economic structures, where sole-traders and small enterprises still exist but borrowed capital and complex organizational structures play a dominant role. Borrowed capital often changes the conditions for responsible behavior because borrowed capital was formed from the savings of third persons. This alone might influence an investor's risk-taking attitudes.

The background for such a behavioral impact is the so-called leverage effect, which reflects the level of borrowed capital. Usually the return on equity in a firm is higher than the market interest rate (the so-called risk-free interest rate). If an investor can earn 10-percent interest on an investment in his / her own firm and the market interest rate is just 5 percent, borrowing is rational because the profit is increased by the 5 percent of the investment financed from borrowed capital. If this profit is added to the profit on the equity capital, the return on equity increases from 10 percent at assumed 100000 currency units of equity capital and zero borrowed capital to 15 percent at 50000 currency units of equity capital, to even 30 percent at 20000 currency units of equity capital to infinite at zero equity capital (see Figure 9). The leverage effect is even boosted if the excess equity capital can be invested in similar investment projects that offer the same return. At an equity investment of 10000 currency units per investment, 10 investment projects of 100000 currency units each can be financed so that the profit increases from 10000 currency units in the case of 100-percent equity financing to 55000 currency units in the case of 10-percent equity financing. Therefore, it seems rational to employ borrowed capital, but this use is connected with substantial risks dependent on the equity/borrowed capital ratio. 
The entrepreneur is always confronted with the risk that his / her return on equity might not be sustainable but could decrease in the future. In the case of using borrowed capital, an additional risk arises: if the rate of return declines, the borrower can no longer service the debt (interest payment and amortization of the borrowed capital). Now it depends on the risk expectations and evaluation of the single entrepreneur if the input of borrowed capital changes his/her attitudes about risk taking. Long-term experience and some empirical evidence seem to prove that the input of debt capital increases the willingness to take higher risks especially in cases where limited liability exists (e.g., limited liability companies and joint stock companies).

Figure 9

EQUITY CAPITAL, BORROWED CAPITAL, AND RETURN ON EQUITY

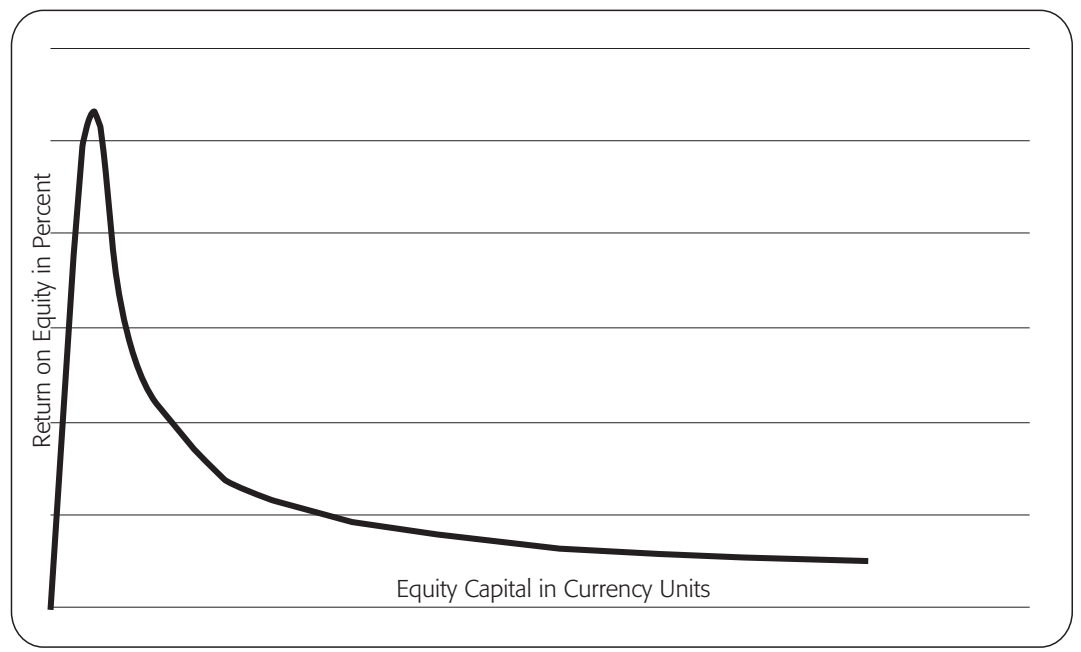

Source: Own calculations.

The input of borrowed capital combined with limited liability arrangements already sets incentives for investors to take more risks than in the case of full equity financing. If then the intrinsic motivation stemming from ethical paradigms like the "decent tradesman" is buried in oblivion and no longer communicated as a leading image, the obstacles for risk-taking behavior are eroded more and more.

As long as many economists are of the opinion that morality and ethics are just problems of philosophy and not part of daily economic life, it is no wonder that critical developments in our societies are coming to the surface and into people's conscious- 
ness. Since the very beginning of the theory of economic thought, economists have been fully aware that serious market failures do exist, which must be overcome by efficient governmental regulation. But if market failures are not cured and then are accompanied by moral failures of the agents acting in the markets (the suppliers and demanders of goods and services), ${ }^{6}$ the entire social and economic system could even be jeopardized. Only efficient government regulations ("good governance") and education in fundamental values can prevent us from such catastrophes.

Another risk for spreading moral failures is to be seen in the complex economic structures that exist in modern economic systems. The sole trader and the personal entrepreneur relying on equity capital and self-responsibility are still quite typical in some happy countries with a large sector of small and medium-sized enterprises (SME); but in all highly developed countries, big incorporated companies with sophisticated organizational structures dominate. For reasons of simplicity, Figure 10 shows some of the complex governance relations.

If governance decisions are delegated to managers, in terms of modern institutional economics, agents emerge who manage the owner's equity capital or, in case of corporations, that of the shareholders, who are the principals in our approach. Principally the managers (or the board of directors or chief executive officers [CEOs]) have to act in the interests of the shareholders to maximize the shareholders' value. In social-market-oriented societies like Germany, stakeholders' interests are also legally ensured ("Mitbestimmungsgesetz" or Co-Determination Act; see Figure 10) to safeguard the common welfare obligation of private property. Then additional agents appear on the scene representing something other than the owners' interests. Managers are not solely acting in the interest of shareholders, but developing strong interests of their own, especially interests to maximize their own wealth. In extreme cases, these interests become dominant so that the equity capital bases of the shareholders may even be destroyed (exploitation of the shareholders by the management). But this is only one PAP; many others are also involved.

Trade union officials, whose main task is to represent the interests of employees (who are the principals in that relationship), also develop their own incentives, which may conflict with those of their clients. Certainly, a trade union representative in a supervisory board or even a board of directors develops his/her own interest for higher remuneration. Also, numerous PAPs can be involved in the relationships between supervisory board, shareholders, and managers. Hence, complex governance structures are inevitably connected with multi-stage PAPs.

\footnotetext{
${ }^{6}$ Markets are just societal instruments like ethics; if the agents (suppliers and / or demanders) on the markets are acting immorally, market outcomes will be immoral, too. For details see Petersen (1993: 128, 138).
} 
Figure 10

CORPORATE GOVERNANCE STRUCTURE IN GERMANY

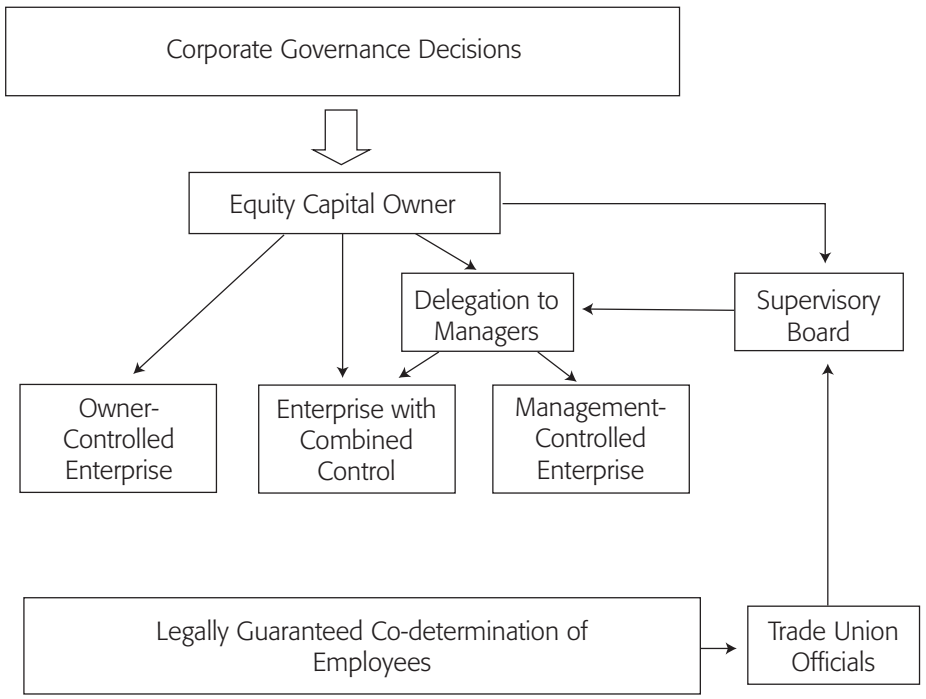

Source: Figure 10 was developed in rough correspondence to Wöhe and Döring (2005: 71).

A specific example of a collapse of corporate social responsibility can be seen in the previously described crisis of the financial markets (for details see Petersen [2012c]). As already mentioned, a modern, efficient financial sector steered by responsible financial managers acting in the interests of capital owners but also in their own personal interests remains an important target of national and international economic policy. The abolishment of capital transaction controls, the globalization process itself, and the implementation of information technologies broadened financial markets, created new financial products, and gave rise to new types of financial institutions, less or almost completely unregulated by national supervisory authorities.

Investment traders and bank managers on short-term contracts misused their mandates predominantly in their own income and property interests and consequently destroyed trust in the financial system, with far reaching consequences for future development. And all that happened despite the fact that all these institutions, whether private, partly in a public-private-partnership (PP)), or totally public, had ethical guidelines and corporate social responsibility declarations in their company presentations. ${ }^{7}$

\footnotetext{
${ }^{7}$ See, for example, Deutsche Bank's internet presentation (n.d.), This has not prevented Deutsche Bank's cEOs and asset managers from playing a very questionable role during the subprime mortgage hype in the U.S. See the 2012 Der Spiegel exposé.
} 
Therefore, complexity must be reduced, transparency increased, and information systems substantially improved. Managers have to be reminded of the guiding principal of a decent tradesman, so they follow the obligations of corporate social responsibility once again. They need to internalize the traditional knowledge that finance and banking depend on the clients' trust in the monetary system. This allows principals to regain control over the system and redevelop the necessary trust which is indispensable for future growth and welfare. But this recovery has to be accompanied by more efficient public (macro-prudential) regulation, which must be implemented globally even by countries like the U.S. and the UK, where the reluctance to take such measures is still much too strong.

\section{Conclusions}

Both the economic and political systems urgently need efficient rules and regulations, which have been extensively discussed in political and economic theory. The necessary technical conditions are more or less obvious today because positive examples exist. But even in these cases, serious shortcomings prevail, as the 2007/ 2008 world financial crisis demonstrated. The predominantly well-known technical conditions often do not function because human beings display serious shortcomings with regard to the internalization -or internalize insufficiently- of the underlying value system. This is due to the fact that in many discussions technical conditions predominate, while the ethical foundations often remain ambiguous. Almost every corporation has its own CsR guidelines, which all sound quite convincing and are usually part of the company presentation. But this often remains a pure marketing strategy with no consequences in real actions. The most prominent example is the behavior of the managers as agents of banks and insurance companies, who should be fully aware that financial markets only function in the long run when the respective actors trust each other and are also sufficiently trusted by the public. The system inevitably collapses if this trust is destroyed. That has not hindered most agents from behaving like lemmings to protect their self-interest over their principals' interests. Certainly, shortterm work contracts created some questionable negative incentives, but there has also been massive criminal impetus.

If one discusses with the predominantly young financial brokers and traders, it becomes obvious that their motivation is very similar to that which dominates in another field of daily life: professional sports. They want to earn the highest return in the shortest possible period -most of the leading international soccer clubs are almost bankrupt. The international financial system is not a casino, and "casino capi- 
talism" (Sinn, 2009) as executed in recent years destroys the very basis of democratic, market-oriented free societies. What is badly needed is a general outcry for a new ethical foundation of politics and economics even in our highly developed countries and all over the world. If computers and mathematical algorithms replace human beings in financial markets -this is called electronic trading and banking-, not surprisingly, social responsibility has fallen victim to technical progress. But this technical progress destroys the very basis of our societies. We have to reduce complexity and develop more skepticism about easy, quasi-automatic solutions.

The lessons one can learn from the last financial crises are manifold. The financial sector as part of the service sector has developed too strong self-interests expressed in extraordinary rates of returns, salaries, and bonuses: the self-interest of agents prevail over the ownership interests of principals. Therefore, the financial sector's role has become more and more relevant, almost displacing not only the owners' interests but also political influences. The financial sector has to be reduced to its classical role of serving the real economy regulated by strong national states and international organizations. Agents in the financial sector must follow a personally binding code of conduct so that the people's trust in financial institutions is safeguarded and not sacrificed for short-term individual advantages.

Most importantly, arbitrage and speculation are often instruments to improve market conditions and move toward equilibrium. Hence, speculation in financial markets may positively impact goods markets and increase welfare. In the case of asymmetric information and excessive power on the supply side, agents are able to induce price hikes by artificially increasing demand, as happened with subprime mortgages before the 2007/ 2008 crises. Underlying Ponzi schemes evoke price bubbles, ${ }^{8}$ which eventually burst and might even destroy formerly well-functioning markets. Crashes of financial markets can infect goods markets and drag the real sector into recession. This kind of speculation destroys well-being; therefore, countermeasures have to be implemented in the form of macro-prudential solutions for monetary policy and regulation.

But agents' long-term self-interests should also be directed against welfare-destroying speculation. In spite of the fact that the media has named some "heroes" as having first detected the coming financial market crash, almost every merely reasonably informed economist had all the necessary information about the fundamental disequilibrium in the U.S. mortgage system and beyond. But this knowledge did not stop agents from blowing the bubble up as long as possible because their intrinsic motivation was dominated by false incentives. Therefore, financial experts should

\footnotetext{
${ }^{8}$ For examples of price bubbles see Van Boening, Williams, and LaMaster (1993).
} 
put more effort into developing strategies that in the future will safeguard the stability of national as well as international financial markets. What is important is no longer innovations of new complex financial products important, but rather the implementation of corrective measures, which will serve the long-term interests of the clients so that trust in the financial sector is restored. Such measures include quality labels for financial products, certifications, international product liability, and reliable, re-producible, and independent rating procedures. Liability and product recall by issuers would be clear signals of the degree of reliability (and the risks involved) and would improve transparency. Hence, consumers' protection is in line with the fundamental self-interests of financial agents because it ensures the long-term functioning of the markets. Voluntary product guarantees are a form of micro-prudential regulation corresponding to CSR obligations and substituting the need for much stronger regulatory measures by state authorities.

The concentration process within the financial sector has to be stopped by appropriate regulation to secure sufficient competition among the different institutions of the banking and insurance sector. Orienting exclusively to big clients (large enterprises or rich individuals) has to be corrected in favor of a banking and insurance scheme in which the average citizen is the focus of financial services. A combination of savings, cooperative, and private banks is of utmost relevance. The old German "house bank" system has been a good example. Private clients and firms have organized their debit and credit relations using a single bank, and the bank managers were perfectly informed about their credit risks independently of other agents (like the rating agencies). The Basel Accords have partly destroyed this system, which is of special value for the SME sector. But in the meantime, at least the smaller financial institutions have realized that while such a system may lead to a decreasing rate of return, it also increases safety in investments through trust.

Hence, the SME sector needs corresponding small and medium-sized banks (SMB), with managers closely connected to the clients and familiar with their individual risk profiles. Manifold securitization brings enormous information losses and the risk of misuse. Multi-agent systems formed by shadow banks and rating agencies suffer from serious PAPS, difficult to control adequately by governmental regulation. The influence of misled, inadequately-controlled agents contributes to speculative bubbles and pyramid and avalanche effects so that the fundamental economic data are no longer of relevance for stock markets and firms' capitalization. Short-term speculative interests then endanger the long-term well-being of whole societies.

In developing and emerging countries, SMES as well as SMBS must be supported in the development process until they form the backbone of the economy and display sustainable business models. Conventional banking methods have to be com- 
bined with modern financial products, which must be characterized by an adequate rate of return and a transparent risk/reward ratio. Cooperative credit institutions acting in the interest of bank clients are also a promising approach for limiting the influence and the concentration within the globalizing market. This mainly creates advantages even for smaller lenders to gain access to international capital and to overcome situations of national capital shortages. But just as important as an efficient SMB system is citizens' trust or mistrust in the national system of governance.

Last but not least, the European currency system will only survive if the leading politicians in the eurozone are courageous enough to emancipate themselves from the U.S. and the UK, both of which obviously have different interests and concepts of the role of financial markets in their respective economic systems. Europe badly needs a financial architecture of its own to separate risk profiles into conventional banking, investment banking, and high-risk areas, in which the super-rich can play in the "casino style." Of utmost importance is monetary policy returning to a "sound policy" that guarantees a positive real interest rate in the medium- and long-term perspective. Only at a positive real interest rate are the necessary savings incentives set for individuals, who are required to overcome the problems of demographic change by partly capital-funded insurance schemes. The future of social security in our societies is jeopardized without a strong compound-interest effect in the private and public insurance schemes. Therefore, as soon as possible, the ЕСв has to change its current cheap-money policy.

\section{BIBLIOGRAPHY}

Borio, Claudio, and Piti Disyatat

2011 Global Imbalances and the Financial Crisis: Link or No Link? Basel, Bank for International Settlements, BIS Working Papers no. 346.

\section{DER SPIEGEL}

2012 “Die Zocker AG - Die dubiosen Geschäfte der Deutschen Bank," no. 5, January 30.

DeUTSChE BANK

n. d. https: / / www.deutsche-bank.de/csr/index.htm.

Diamond, Douglas W., and Raghuram G. Rajan

2009 "The Credit Crisis: Conjectures about Causes and Remedies," American Economic Review, vol. 99, pp. 606-610. 
eсв (European Central BanK)

2012 Long-term interest rate statistics for EU Member States, uploaded January 1, 2013, https: / / www.ecb.europa.eu/stats/money/long/html/index.en.html.

EMONS, WINAND

1997 "Credence Goods and Fraudulent Experts," The RAND Journal of Economics, vol. 28 , no. 1, 107-119.

\section{EURO CRISIS MONITOR}

2012 Institute of Empirical Economic Research, Osnabrueck University, uploaded January 1, http: / / www.eurocrisismonitor.com/index.htm.

Federal Reserve BanK of St. Louis

2012 Effective Federal Funds Rate, uploaded January 1, http:/ / research.stlouis fed.org/ fred2/series/FEDFUNDS.

Federal Reserve BoARd

2011 Flow of Funds Accounts, uploaded October 19, http:/ / www.federalreserve .gov/ releases/z1/Current/data.htm.

Hanson, Samuel G., Anil K. Kashyap, and Jeremy C. Stein

2011 "A Macroprudential Approach to Financial Regulation," Journal of Economic Perspectives, vol. 25, no. 1, pp. 49-70.

Khoperia, Lela, Davit Narmania, and Nata Goderdzishvili

2012 The Role of Government and Public Policies in Promoting Corporate Social Responsibility - An Analytical Overview and Recommendations to the Georgian Government (Executive Summary), Tblisi, The Centre for Strategic Research and Development of Georgia and Friedrich Ebert Stiftung.

KLINK, DANIEL

2008 "Der Ehrbare Kaufmann - Das ursprüngliche Leitbild der Betriebswirtschaft lehre und individuelle Grundlage für die CSR-Forschung," in Joachim Schwalbach, ed., Corporate Social Responsibility, Zeitschrift für Betriebswirtschaft/Journal of Business Economics, Special Issue 3, pp. 57-79.

McKinsey AnALYTics

2010 McKinsey Global Economic Database; World Development Indicators of the World 
Bank; Farewell to cheap capital? The implications of long-term shifts in global investment and saving, McKinsey Global Institute, http: / / www.mckinsey.com/ / media/McKinsey / dotcom/Insights\%20and\%20pubs / MGI/ Research / Fi nancial $\% 20$ Markets / Farewell $\% 20$ to $\% 20$ cheap $\% 20$ capital / MGI_Farewell _to_cheap_capital_full_report.

MishKIN, FREDERIC S.

2011 "Over the Cliff: From the Subprime to the Global Financial Crisis," Journal of Economic Perspectives, vol. 25, no. 1, pp. 49-70.

\section{Obstfeld, Maurice, and Kenneth Rogoff}

2009 "Global Imbalances and the Financial Crisis: Products of Common Causes," paper presented at the Federal Reserve Bank of San Francisco, Asia Economic Policy Conference, Santa Barbara, California.

oecd (Organisation for Economic Co-operation and Development)

2011 "Promoting Longer-Term Investment by Institutional Investors: Selected Issues and Policies," Discussion note in OECD Journal: Financial Market Trends, vol. 2011, no. 1, www.oecd.org/ dataoecd/37 / 42 / 48281131.pdf, p. 145-164.

\section{Pelizzon, LorianA}

2014 Global Financial Turmoil: Does Connectedness Matter? SAFE Newsletter, Center of Excellence, Q1/2014.

\section{Petersen, Hans-Georg}

2012a “Armut, Reichtum und Humankapital," Jahrbuch für Wirtschaftswissenschaften/Review of Economics, vol. 63, no. 2, pp. 236-264.

2012b "Poverty, Human Capital and the Tax and Transfer Bases: The Role of Education for Development and International Competition," in Bala Batavia, Jin Wook Choi, and R. Hema, eds., Global Integration, National Strategies and Sectoral Impact. Studies in Economic Transformation and Public Policy, Lucknow, India, Indian Institute of Management/The Athenian Policy Forum/Sidma Press, pp. 51-74.

2012c "Principal-Agent-Problems, Risk Management and Social Responsibility: Moral Limitations for Efficient Governance," paper presented at the MultiStakeholder Forum “The Role of Government and Public Policies in Promoting Corporate Social Responsibility" organized by The Center for Strategic Research and Development of Georgia and Friedrich Ebert Stiftung, Tbilisi, Georgia, April 27. 
2011 "The Role of Credit and Banking and the Crisis of the Financial Markets - Lessons for Financing the sme Sector," in A.V. Vakhabov et al., eds., The Role of Banking and Financial System in the Development of Small Business and Private Entrepreneurship, Tashkent, Central Bank of the Republic of Uzbekistan, Banking Association of Uzbekistan and the Banking and Finance Academy, pp. 27-30.

2010 "Steuern in fragilen Staaten - Empfehlungen für die Entwicklungszusammenarbeit," Finanzwissenschaftliche Diskussionsbeiträge 61, Potsdam, University of Potsdam.

2004 "Redistribution and the Efficiency / Equity Trade-off," Studi economici, vol. 82, no. 1, pp. 5-42.

1993 Ökonomik, Ethik und Demokratie. Zu einer Theorie der Effizienz und Gerechtigkeit offener Gesellschaften, Baden-Baden, Nomos Verlagsgesellschaft.

Petersen, Hans-Georg, and Klaus Mueller

1999 Volkswirtschaftspolitik, Munich, Vahlen.

Petersen, Hans-Georg, and Alexander Martin Wiegelmann

2013 "Risk Taking, Principal Agent Problems and Breakdown of Corporate Social Responsibility (CSR): How to Reestablish Safe-Assets and Capital Funding for Social Security," Equilibrium, vol. 8, no. 2, pp. 7-30.

RAWLS, JOHN

1999 A Theory of Justice, Cambridge, Massachusetts, Harvard University Press.

Securities Industry and Financial Markets Association

2011 U.S. Securitization, online as of September 6, http:/ / www.sifma.org/ research/ statistics.aspx.

SERVEN, Luis, and Ha NGUYEN

2010 Global Imbalances Before and After the Global Crisis, Policy Research Paper no. 5354, World Bank.

SinN, HANS-WERnER

2012 Die Target Falle. Gefahren für unser Geld und unsere Kinder, $4^{\text {th }}$ ed., Munich, Hanser.

2009 Kasino Kapitalismus-Wie es zur Finanzkrise kam, und was jetzt zu tun ist, $2^{\text {nd }}$ ed., Berlin, Econ. 
STEIN, JEREMY

2010 "Securitization, Shadow Banking and Financial Fragility," Daedalus, vol. 139, no. $4,41-51$.

Van Boening, Mark V., Arlington W. Williams, and Shawn LaMaster

1993 "Price Bubbles and Crashes in Experimental Call Markets," Economic Letters, vol. 41, no. 2, pp. 179-185.

Wiegelmann, Alexander Martin

2013 "Risikotransfers in den Schattenfinanzsektor. Regulatorische und geldpolitische Reaktionen auf die Finanzkrise 2007 / 08," Postdam, Germany, dissertation, University of Potsdam.

WIKIMEDIA COMMONS

2012 Net Yield of 10 Years Government Bonds in Some Member States of the Euro Zone, uploaded January 1, http: / / commons.wikimedia.org/wiki/File:Long-term _interest_rates_(eurozone)_(1993-2011)de.png).

WÖHE, GÜNTER, and ULRICH DÖRING

2005 Einführung in die allgemeine Betriebswirtschaftslehre, $22^{\text {nd }}$ ed., Munich, Vahlen. 